Short case report

\title{
Aortic incompetence and active myocarditis in Reiter's disease
}

\author{
PATRICK COLLINS \\ Leicester Royal Infirmary, Leicester LE1 5WW
}

The cardiovascular complications of Reiter's disease, rank amongst the less frequently encountered manifestations.

Paronen (1948) reported clinical and electrocardiographic data on a series of 344 patients; $6 \cdot 7$ per cent, had findings consistent with carditis, and of these 23 patients, sixteen had myocarditis only, four had myocarditis and pericarditis, and three had isolated pericarditis. $\mathrm{He}$ found no evidence of endocarditis.

Clinical evidence of aortitis is extremely rare. We have been able to find documented evidence of nineteen cases only (Csonka, Litchfield, Oates, and Willcox, 1961; King, 1964; Gamp, 1956; Kellgren and Ball, 1959; Pearson, 1963; Rodnan, Benedek, Shaver, and Fennell, 1964; Toone, Pierce, and Hennigar, 1959; Dixon, 1960; Zvaifler and Weintraub, 1963; Cliff, 1971), though other cases in which the distinction between Reiter's disease and ankylosing spondylitis was doubtful have been reported (Bontoux, Bastin, and Coste, 1967).

The following case is reported because of the rarity of aortic incompetence in this syndrome, and because carditis was the sole active manifestation of Reiter's syndrome when the patient was seen by us.

\section{Case report}

A 49-year-old man was transferred to the General Infirmary at Leeds on March 20, 1970. He had previously been admitted to Keighley Victoria Hospital on

Received for publication October 26, 1971

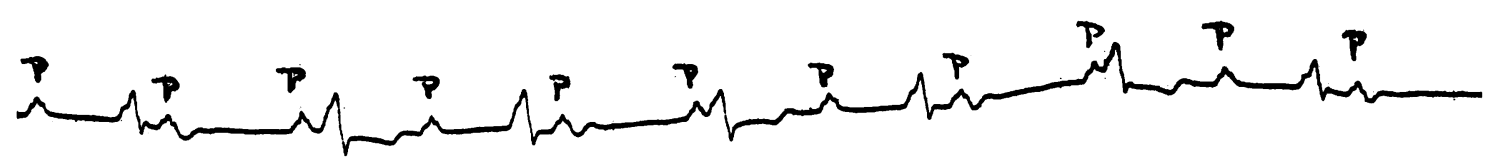

February 9, 1970, with a 2-week history of rapidly progressive exertional dyspnoea which culminated in a severe sustained attack of dyspnoea at rest.

\section{History}

He gave a past history of abacterial urethritis in 1941, followed by conjunctivitis and pain in the left buttock and hip. These symptoms resolved over the course of 6 weeks. In 1956 he had intermittent low back pain and an attack of abacterial haemorrhagic cystitis. He was then well until 1963 when he developed lumbar pain, followed by a recurrence of non-specific urethritis and conjunctivitis together with arthritis involving the left knee and shoulder, the right great toe, and the proximal interphalangeal joint of the right little finger. At this time his heart was clinically and electrocardiographically normal. He had no bacteriological evidence of gonorrhoea, and serological tests for syphilis and tests for the rheumatoid factor were negative. The antistreptolysin-O titre and serum uric acid level were normal.

$\mathrm{He}$ was treated with prednisolone and tetracycline, and the symptoms resolved in the course of 14 weeks.

Since 1963 he had had no recurrence of arthritis, urethritis, or conjunctivitis. He had no past history of rheumatic fever.

On February 2, 1970, he presented with severe exertional dyspnoea and on admission to the Keighley Victoria Hospital was found to have aortic incompetence. An electrocardiogram revealed complete heart block and idioventricular rhythm at a rate of $66 / \mathrm{min}$. (Fig. 1). He was treated with digoxin $0.25 \mathrm{mg}$. twice daily, and Frusemide $40 \mathrm{mg}$. daily, after which he improved. Subsequent electrocardiograms revealed first-degree heart block (P-R interval 0.48 sec.) with left bundle branch block (Fig. 2) followed by second-degree heart block (Wenkebach type) with left bundle branch block (Fig. 3).

FIG. 1 Complete heart block on February 2, 1970 


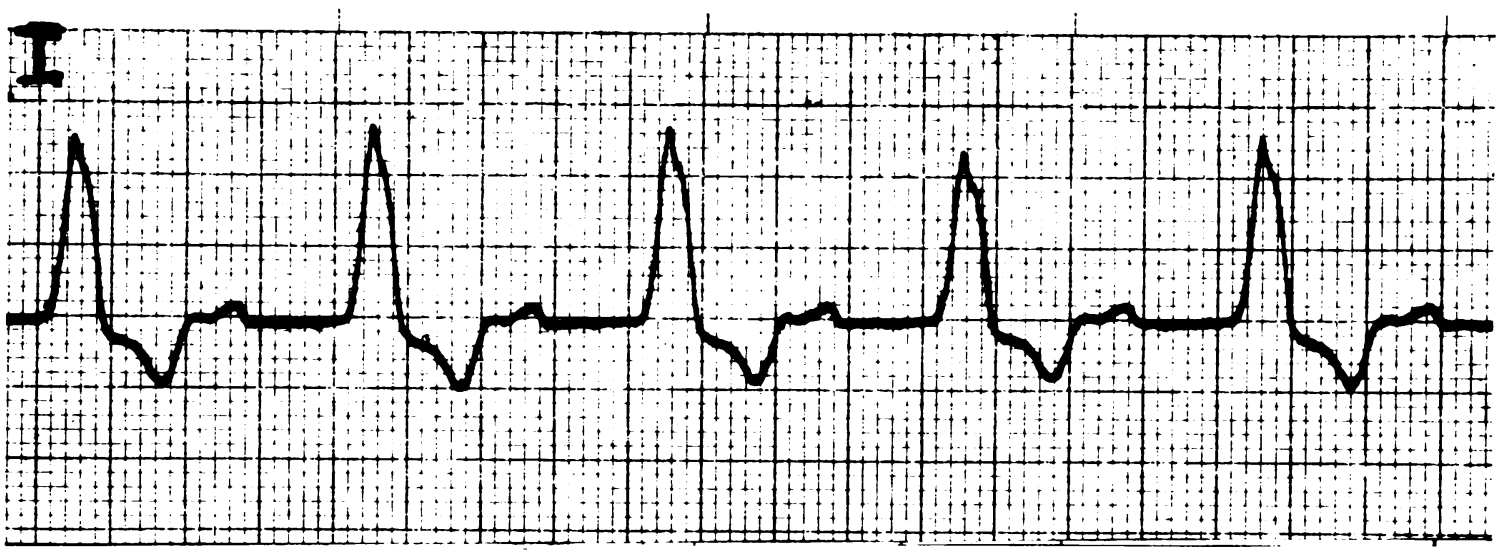

FIG. 2 First-degree heart block and complete left bundle branch block on February 11, 1970

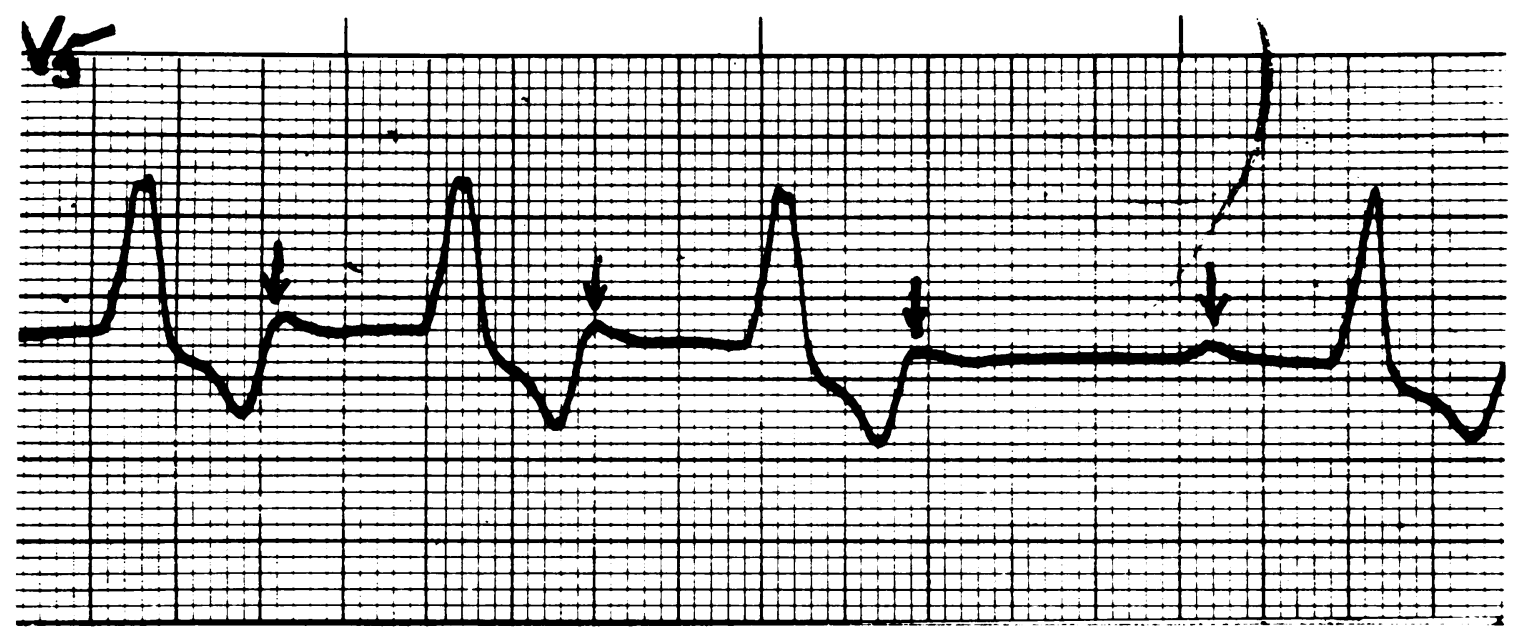

FIG. 3 Second-degree heart block and complete left bundle branch block on February 20, 1970

\section{Examination}

On transfer to the General Infirmary at Leeds, examination revealed a man of average build who was afebrile and now dyspnoeic only on moderate exertion. The pulse was collapsing and regular at $72 / \mathrm{min}$., blood pressure was 190/70, and capillary pulsation was seen in the nail beds. The jugular venous pressure was not raised, there was no peripheral oedema, and the lung bases were clear. The apex beat was in the 6th left intercostal space, in the mid-clavicular line, and the cardiac impulse was thrusting in character. Auscultation revealed an apical third heart sound, a basal systolic murmur, and a moderately loud early diastolic murmur, conducted down the left sternal edge. There was no evidence of urethritis, arthritis, conjunctivitis, iritis, or mucocutaneous lesions.

\section{Laboratory investigations}

Erythrocyte sedimentation rate $48 \mathrm{~mm}$. 1st hr (Westergren). The Wassermann reaction, Reiter proteincomplement fixation test, fluorescent treponemal antibody absorption test, and Treponema pallidum immobilization test all gave negative results. Blood cultures were sterile. $X$ rays of chest, lumbar spine, and feet were normal; the sacroiliac joints showed minor sclerotic changes.

\section{Electrocardiograms}

18.3.70. Second-degree heart block (Wenkebach type), ventricular ectopic beats, left axis deviation, and left ventricular hypertrophy (Fig. 4). 


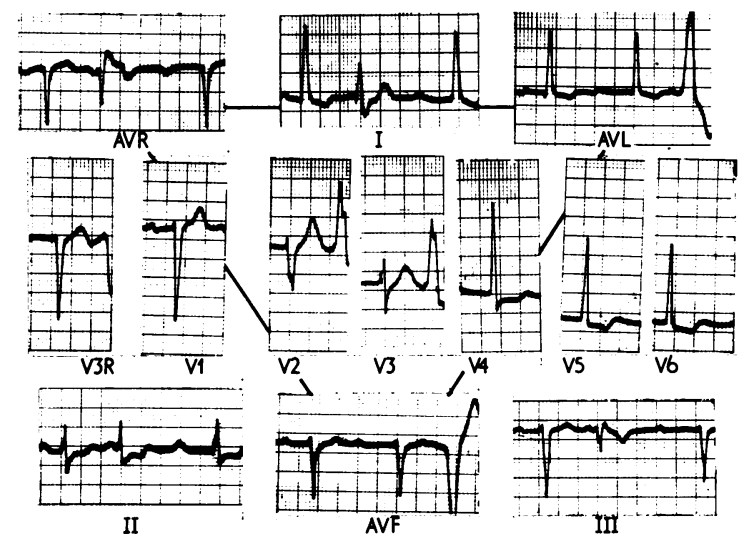

FIG. 4 Second-degree heart block on March 18, 1970 (see text)

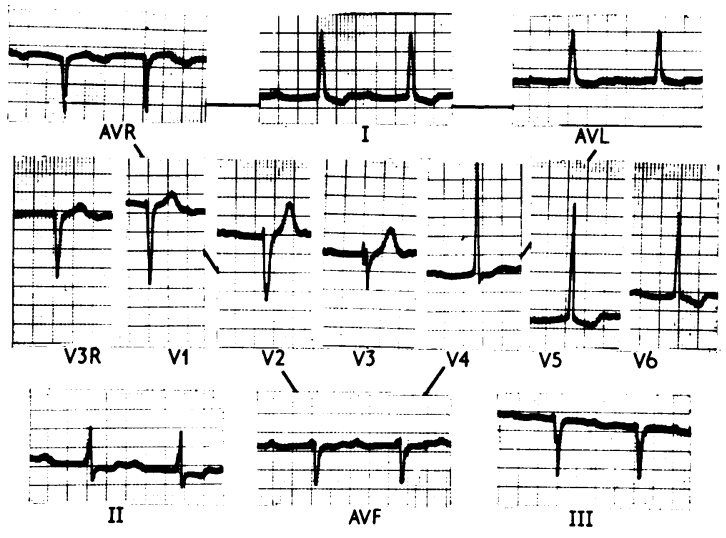

FIG. 5 First-degree heart block on March 20, 1970 (see text)

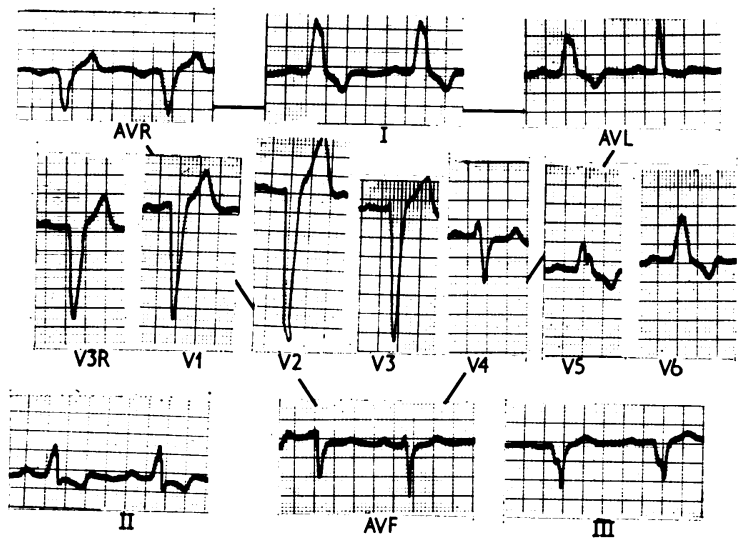

F IG. 6 First-degree heart block on April 1, 1970

(see text)
20.3.70 First-degree heart block ( $P-R$ interval $0.52 \mathrm{sec}$.), left axis deviation, and left ventricular hypertrophy (Fig. 5).

1.4.70 First-degree heart block and left bundle branch block (Fig. 6).

\section{Discussion}

This patient had a history of the characteristic triad of abacterial urethritis, conjunctivitis, and arthritis consistent with Reiter's syndrome, on two occasions. There was no history of rheumatic fever, and serological tests for syphilis have been consistently negative. A cardiac lesion was not in evidence until February, 1970. On the basis of the evidence available, we feel confident that the aortic incompetence is a direct result of the aortitis of Reiter's disease. The long latent period between the first episode of Reiter's disease and the appearance of aortic incompetence seems to be characteristic. In those cases which have been fully documented, this interval has varied between 4 and 31 years (Csonka and others, 1961; Rodnan and others, 1964).

The electrocardiographic changes in Reiter's disease are usually transient, lasting for only a few weeks, and are seen in association with the more characteristic manifestations. In a few patients, however, ECG changes have persisted. When ECG changes are seen, these are usually those of impaired atrioventricular conduction, the commonest being prolongation of the PR interval (Csonka and others, 1963; Paronen, 1948; Feiring, 1946). Higher grades of heart block are extremely rare. Seconddegree heart block of the Wenkebach type has been reported by Warthin (1948), and complete heart block by Trier (1950); the second patient of Rodnan and others (1964) developed complete heart block transiently, and he also had transient atrial fibrillation and atrial flutter, but there was also evidence of myocardial infarction which could have been responsible for these disturbances of rhythm.

Left bundle branch block and right bundle branch block have each been reported on one occasion, by Toone and others (1959) and Weinberger, Ropes, Kulka, and Bauer (1962) respectively. Other ECG abnormalities which have been encountered are widening of the QRS complex (Paronen, 1948; Hall and Finegold, 1953), and T-wave inversion (Paronen, 1948; Warthin, 1948).

ST segment elevation of pericarditis, with or without clinical evidence, has been described by Csonka and others (1961), Paronen (1948), and Mayne (1955).

We feel that the case described above is of interest in view of the fact that aortic incompetence and myocarditis, as evidenced by a changing 
electrocardiographic pattern from complete heart block through second-degree heart block to firstdegree heart block, with intermittent left bundle branch block, and a raised erythrocyte sedimentation rate, were the sole active manifestations of Reiter's disease. The characteristic arthritic features had not been actively present for 7 years.

\section{Summary}

A case is presented of aortic incompetence and active myocarditis in Reiter's disease.

I should like to thank Dr J. A. H. Hancock for his help and advice in the preparation of this paper.

\section{References}

Bontoux, D., Bastin, R., and Coste (1967) Rev. Rhum., 34, 592

Cliff, J. M. (1971) Ann. rheum. Dis., 30, 171

Csonka, G. W., Litchiteld, J. W., OAtes, J. K., and Willcox, R. R. (1961) Brit. med. f., 1, 243

Dixon, A. St. J. (1960) Ann. rheum. Dis., 19, 209

FeIRING, W. (1946) Ann. intern. Med., 25, 498

GaMP, A. (1956) Münch. med. Wschr., 98, 334
Hall, W. H., and Finegold, S. (1953) Ann. intern. Med., 38, 533

KellgReN, J. H., and Ball, J. (1959) Brit. med. f., 1, 523

KING, A. J. (1964) 'Recent Advances in Venereology', p. 435. Churchill, London.

MAYNE, G. O. (1955) Brit. F. vener. Dis., 31, 238

Paronen, I. (1948) Acta med. scand., 131, Suppl. 212, p.63

Pearson, C. M. (1963) Ann. intern. Med., 59, Suppl. 4 (No. 5, pt 2), p.62

Rodnan, G. P., Benedek, T. G., Shaver, J. A., and Fennell, R. H. (1964) f. Amer. med. Ass., 189, 889

Toone, E. C., Pierce, E. L., and Hennigar, G. R. (1959) Amer. F. Med., 26, 255

Trier, M. (1950) Acta med. scand., 138, Suppl. 239, p. 123

Warthin, T. A. (1948) Amer. F. Med., 4, 827

Weinberger, H. W., Ropes, M. W., Kulka, J. P., and BAUER, W. (1962) Medicine (Baltimore), 41, 35

Zvaifler, N. J., and Weintraub, A. M. (1963) Arthr. and Rheum., 6, 241

Insuffisance aortique et myocardite active dans la maladie de Reiter

SOMMAIRE

On présente un cas d'insuffisance aortique avec myocardite active dans la maladie de Reiter. 